\title{
The Sounds of the Christians in Northern Nigeria: Notes on an Acoustic History of Bachama Christianity
}

\author{
Niels Kastfelt
}

The lived experience of African Christianity is expressed in the endless variety of forms in which biblical and other Christian texts are read, listened to, apprehended, and turned into ritual and social practice. In this chapter I approach the lived Christianity of Africans through one of its important but generally understudied means of communication and expression, that of sound, starting from the simple observation that African Christian practice is not only the result of reading texts but also of listening to sounds. Anybody who has lived in or visited an African community will know that it has its distinct religious soundscape, these days not the least shaped by Pentecostal churches and Islamic reform movements which have transformed the public soundscapes of Africa, and also made them a great deal louder. My focus is not, however, on the contemporary soundscapes of African Christianity but on one of its historical forms, a goal which involves trying to reconstruct what an African Christianity sounded like at the beginning of the twentieth century. The purpose of the chapter is twofold: to reconstruct the sounds of an African Christianity and, methodologically, to illustrate how it may be done.

The Christianity I am discussing is that of the Bachama-speaking community in the Adamawa region of northeastern Nigeria. Missionaries from the Danish branch of the Sudan United Mission first settled in the Bachama town of Numan in 1913 to work among the Bachama and neighboring ethnic groups, and the Bachama community is today predominantly Christian with the Lutheran church as the largest and most significant denomination. ${ }^{1}$

1 For the general history of the Danish Sudan United Mission in Adamawa and of Bachama Christianity see Niels Kastfelt, Kulturmøde i Nigeria. Mødet mellem Bachamafolket, engelske koloniembedsmcend og Dansk Forenet Sudan Mission (Copenhagen: G.E.C. Gad, 1981); Niels Kastfelt, Religion and Politics in Nigeria. A Study in Middle Belt Christianity (London: British Academic Press, 1994); Mogens Jensen, Two Men and Their Mission. Anton Marius Pedersen, Niels Høegh Brønnum and The Danish United Sudan United Mission 1905-1925, trans. David 
My first point of departure is a conversation I had with an old Bachama Christian, Pastor Obida Mbodwam, in August 1982 in Numan. Pastor Obida was a young boy when the Danish missionaries arrived in Numan in 1913, and I asked what had particularly attracted him to the missionaries and their message. He answered that two things were decisive - that the missionaries composed new songs based on traditional Bachama tunes, and that they talked about eternal life, making it clear that the musical element was the more important. ${ }^{2}$ The second point of departure is a remark I have often heard from old Bachama Christians thinking back to the period before the Second World War. They all recalled that when you lived in a Bachama village you could always hear the Christians approaching your village because they were singing the new Christian songs composed to old Bachama tunes. You could recognize the Christians by the sounds of their tunes without necessarily being able to hear the words of their songs.

To these early Bachama Christians their new religion had its distinct sound, one which worked in two ways: it could speak to their minds and emotions and be attractive, and it could convey meaning and be an efficient channel of communication.

An old and ongoing debate in the study of African Christianity has focused on the relative significance of orality and literacy in its history. For a long time orality was seen as typical of African Christianity, supposedly reflecting the dominantly oral character of many African cultures. For some time, though, there has been a growing interest in African Christian literacy and much exciting work - by Derek Peterson, Thomas Kirsch, Joel Cabrita, and others - has emphasized the substantial production of vernacular texts in African churches in which Africans reflected upon all kinds of theological, spiritual, and cultural

Clayre (Christiansfeld: Forlaget Savanne, 1997); Margaret Nissen, An African Church is Born. The Story of the Adamawa and Central Sardauna Provinces in Nigeria (Viby, J.: Purups Grafiske Hus, 1968); Nicholas Pweddon, A History of the Lutheran Church of Christ in Nigeria (Numan: The Lutheran Church of Christ in Nigeria, 2005); Asriel S.T. Myatafadi, Peter A. Bartimawus, Edward R. Ishaya and Elisabeth Holtegaard (eds.), A Century of God's Faithfulness (1913-2013): Reflections on the Lutheran Church of Christ in Nigeria (LCCN) (Numan: The Lutheran Church of Christ in Nigeria, 2013).

2 Interview with Pastor Obida Mbodwam, Numan, 31 August 1982. 
matters, making these texts supremely valuable material for studying different forms of not just academic but also "popular" theology in Africa. ${ }^{3}$

Interesting and important as this work is - and I am engaged in this kind of work myself - there is also a need to move beyond this primary focus on texts, reading, and writing, and thereby on the sense of sight, and to focus more on sounds and the sense of hearing in the study of African Christianity. Nancy Rose Hunt has suggested that we need to move "beyond seeing as the primary mode of perceiving the past, by being wakeful to other senses and capacities, especially the field of hearing, producing and muffling sound."4 This call for a sensorial reorientation is linked to the "affective turn" in the humanities and social sciences, which has produced interesting work on the ways in which affect can be embodied "but also be verbalized or penned. It can suffuse a milieu, mark a situation, or stir beings and worlds." ${ }^{5}$

Reflections on the effects of sound have long been part of Christian history, at the least since Augustine who in his Confessiones stressed the peculiar power of sound on the human mind and noted how much more fascinated he had been by sound than by smell. To Augustine the power of sound was a theological problem because it proved how often his mind was led astray by his senses. ${ }^{6}$ In an African context this view resounded centuries later when Joseph Conrad wrote about the suggestive meaning of Congolese drums - carrying "perhaps

3 See, for instance, Derek R. Peterson, Creative Writing. Translation, Bookkeeping, and the Work of the Imagination in Colonial Kenya (Portsmouth, NH: Heinemann, 2004); Derek R. Peterson, Ethnic Patriotism and the East African Revival. A History of Dissent, ca. 1935-1972 (Cambridge: Cambridge University Press, 2012); Thomas G. Kirsch, Spirits and Letters. Reading, Writing and Charisma in African Christianity (New York: Berghahn Books, 2008); Joel Cabrita, Text and Authority in the South African Nazaretha Church (Cambridge: Cambridge University Press, 2014). For a wider discussion see Karin Barber, The Anthropology of Texts, Persons and Publics (Cambridge: Cambridge University Press, 2007).

4 Nancy Rose Hunt, "An Acoustic Register, Tenacious Images, and Congolese Scenes of Rape and Repetition," Cultural Anthropology 23, no. 2 (2008): 224.

5 Nancy Rose Hunt, "Interview with Nancy Rose Hunt," "Acoustic register, tenacious images, and Congolese scenes of rape and repetition: supplementary material" (http://www.culanth. org/articles/106-an-acoustic-register-tenacious-images-and), supplement to Cultural Anthropology 23 (2008): 220-253, accessed March 7, 2016; see also Nancy Rose Hunt, "The Affective, the Intellectual, and Gender History," Journal of African History 55, no. 3 (2014): 331-345 and her A Nervous State. Violence, Remedies, and Reverie in Colonial Congo (Durham: Duke University Press, 2016). For the wider historiographical context see Eiko Ikegami, "Emotions," in A Concise Companion to History, ed. Ulinka Rublack (Oxford: Oxford University Press, 2011), 333-353.

6 St. Augustine, St. Augustine's Confessions, trans. William Watts (Cambridge: Harvard University Press, 1988), vol. 2, Book X, chapter XXXIII, 164-169. For the general context see Christopher Page, The Christian West And its Singers. The First Thousand Years (New Haven: Yale University Press, 2010). 
as profound a meaning as the sound of bells in a Christian country."7 The affective power of sound in the form of drums, church bells, or other media was taken up when later generations of historians and anthropologists began to explore the history and culture of sound. ${ }^{8}$

In the historical study of African Christianity sound has not been much explored as a separate subject. Exciting and important work has been done on African Christian hymns although predominantly from a textual point of view. ${ }^{9}$ I do not call for a specialized or compartmentalized "affective turn" in the study of African Christianity, but simply want to point out the benefits of an acoustic approach and to suggest that it can lead to new understanding. With Hunt and others I suggest that we transcend seeing as our privileged means of approach and focus more on hearing and sounds in the study of African Christianity, and I shall exemplify this by exploring the sounds of Bachama Christianity and suggesting one way of writing an acoustic history of an early 2oth-century African Christianity.

\section{4}

\section{The Soundscape of Early Bachama Christianity}

The first missionary to arrive in Numan in 1913, Dr. Niels Høegh Brønnum, was a medical doctor who was also interested in language and sound. He wanted to evangelize in the vernacular and soon learnt to speak Bachama and before that Hausa. He wrote his first hymn in Bachama in 1913 or early 1914, using a wellknown Bachama tune and basing the words on The Gospel of John, 3:16. ${ }^{10}$ In 1915 he published a Bachama translation of St. Mark and later contributed to

7 Joseph Conrad, The Heart of Darkness, ed. Robert Kimbrough, third edition (New York: W.W. Norton \& Company, 1988), 23; cf. James W. Fernandez, "The Sound of Bells in a Christian Country - in Quest of the Historical Schweitzer," The Massachusetts Review 5 (1964): 537-562.

8 Influential early work in this field includes Alain Corbin, Village Bells. Sound and Meaning in the 19th-Century French Countryside, trans. Martin Thom (London: Papermac, 1999); Steve Feld and Donald Brenneis, "Doing anthropology in sound," American Anthropologist 31, no. 4 (2004): 461-474; Charles Hirschkind, The Ethical Soundscape. Cassette Sermons and Islamic Counterpublics (New York: Columbia University Press, 2006).

9 See for instance Bengt Sundkler, Zulu Zion and Some Swazi Zionists (Oxford: Oxford University Press, 1976); Elizabeth Gunner, The Man of Heaven and the Beautiful Ones of God. Umuntu Wasezulwini Nabantu Abahle Bakankulunkulu. Writings from Ibandla lamaNazaretha, a South African Church, Studies on Religion in Africa XXIV (Leiden: Brill, 2002); Cabrita, Text and Authority.

$10 \quad$ Niels Høegh Brønnum, "Den første Salme paa Bachama," Sudan 6 (1914): 93. An English translation of the song is provided in Niels Kastfelt, "A Song in Kwa Bwatiye by Dr. N.H. Bronnum," Linto 1 (1997): 5 . 
the first Bachama hymn book.11 Other missionaries also composed hymns by combining old Bachama tunes with new words, and so did Bachama Christians and their opponents, making songs an important source for studying the historical development of Bachama Christianity and not the least its vernacular idioms, metaphors and sounds. ${ }^{12}$

Niels Høegh Brønnum wrote an early account of the sounds of Numan around 1913 by focusing on Bachama musical instruments. He demonstrated how the sounds of different musical instruments were carriers of meaning and had implications for feelings, emotions, and sensations. He listed, for instance, eleven different drums, which were distinguished by their physical form, by the sound they produced and by the occasions on which they were used. When the war drum, the hubo duwe, was beaten all the men immediately left for the chief's compound to get ready for battle. "Everybody knows its sound," Brønnum noted. When the tyengye drum was heard in the Bachama village of Bolen women knew they had to stay inside their compounds to avoid being confronted with dangerous spirits wearing wooden masks, which were feared by women who would die if they saw the masks. When the lyenye (elephant teeth) horn was blown in the evening its varying sounds could either signal that the Bachama chief was on his way out of his compound to meet his subjects or that he had retired for the night. The lyenye signaled chiefly presence or absence from the public eye. The pampame, a two to three meters long metal trumpet, was used to praise the chief when he travelled through Bachamaland with his entourage. ${ }^{13}$ These examples suffice to show how the Bachama of $\mathrm{Nu}-$ man and the surrounding villages moved in a soundscape where sound created messages, directions, and emotions which provided the Bachama with a soundmap of social maneuvering.

In order to take the next step and try to reconstruct the soundscape of early Bachama Christianity I ask the same question Robert Darnton asked about the popular songs of 18th-century Paris, "What was the corpus of tunes known to

11 Lemefeme da Yesu Kristo. Markus (Shonga: British and Foreign Bible Society, 1915); Malamto Dymsye. Bachama Hymn Book (Minna: The Niger Press, 1925).

12 See Kastfelt, Religion and Politics in Nigeria, 144-152; Niels Kastfelt, "Afrikanske sange," Teol-information 14 (1996): 11-16; Niels Kastfelt, "Songs and Sleeping Sickness in a Nigerian Village," in (Genklange). Essays om kunst og kristendom tilegnet Nils Holger Petersen på 70-årsdagen, eds. Kristoffer Garne and Lars Nørgaard (Copenhagen: The Faculty of Theology, University of Copenhagen, 2016), 176-182.

13 Niels H. Brønnum, Folkeliv i Sudan, I, Bachamastammens Historie, Sprog, Levemaade og Kultur (Struer: M. Christensens Bogtrykkeri, 1923), 149-153. 
ordinary Parisians in the mid-eighteenth century?"14 And we can argue with Darnton that the tunes known to the people of a culture are a shared "repertoire of tunes, which is peculiar to their culture and which they carry around in their heads" as part of a collective memory which could be powerfully renewed by giving new words to old tunes..$^{15}$ This was what Bachama Christians and Danish missionaries - like many other Christians throughout Africa - did when they composed hymns by giving new words to old tunes as a means of evangelizing and of religious debate. ${ }^{16}$

We must, then, ask the following questions: Which tunes were available to Bachama Christians? Which tunes did they choose? Why did they choose as they did? And what were the consequences of their choices?

In order to answer these questions, I first map the categories of tunes which were available to the Bachama in the 1910 and onwards. The Bachama had different categories of songs which each had their own characteristic tunes. ${ }^{17}$ Most Bachama would easily recognize them and know which category they belonged to. Each category of songs could include a number of tunes which were all so similar that Bachama could distinguish them from the tunes of other categories. When Bachama heard a song, therefore, they were able to identify the category to which it belonged, and the tune and its perception would produce particular intellectual and affective connotations in the listeners. The perception of the sound of the tunes itself was able to determine or direct the meaning of the words, because by hearing the sound of a song Bachama knew the category which provided the framework for understanding its words.

The main categories of Bachama songs were:

\footnotetext{
14 Robert Darnton, Poetry and the Police. Communication Networks in Eighteenth-Century Paris (Cambridge, MA: The Belknap Press of Harvard University Press, 2010), 169.

15 Darnton, Poetry and the Police, 169.

16 Kastfelt, "Songs and Sleeping Sickness in a Nigerian Village."

17 This survey has been made, not least, on the basis of twenty-eight years of conversations with Dr. Nicholas Pweddon, beginning in 1981 and ending with Dr. Pweddon's death in 2009. Especially important for the present discussion was a conversation in Jos on October 4 , 1994. The list is probably incomplete and more types of tunes could possibly be added to the list. See also Nicholas N. Pweddon, "Dyemshi Bondiha: Bachama Praise Songs from Sondo to Rakuma Pwakono," unpublished paper (Madison: University of Wisconsin, Department of African Languages and Literature, 1973).
} 
Dyemshi bwepüle: songs of the followers of spirit worship, that is, the songs especially sung during the main annual festival, the vönön, in the village of Farei at the beginning of the rainy season.

Dyemshi bosoune / dyemshi jiboshe: songs of the jiboshe, people who could transform themselves into something else.

Dyemshi wuro ome: songs for hunting dances, also known as dyemshi ome, songs for hunting. This consisted of two types: songs sung when Bachama chased a prey, and songs which were sung when the hunting was over and the hunters celebrated that the prey had been killed and brought home.

Dyemshi dawe: cutting songs or dancing songs. This also included dyemshi kala-ade, shooting tree songs.

Dyemshi weshibore: wrestling songs.

Dyemshi mbange: dancing songs.

Dyemshi sunga: sword songs.

Dyemshi fwakato: songs of falling, songs sung during a ritual dance performed by women where they took turns in falling backwards and letting themselves be gripped by the other women.

Dyemshi daha: songs of abuse. This also included the dyemshi bagoha, "indirect" songs of abuse where the singers abused a person indirectly without naming his or her name.

Dyemshi wajalle: royal dance songs. These also included songs of ridicule and were sung and danced by members of one of the royal clans, the zomye. The singers ridiculed each other in a humorous and satirical way. They were close to the dyemshi ngbangta, which were songs of ridicule sung by singers from the village of Dong.

Dyemshi kaduwe: songs used by members of a particular ward in the village of Lamurde when cutting grass for the horse of the Bachama chief. The songs were sung under the leadership of a kpadwe and could be abusive about anybody, including the chief himself.

Dyemshi mune: war songs or "songs of men" which were usually sung by one person but which could also be sung by rotating groups of age-mates.

Dyemshi hauto: work or farm songs, literally "hoeing songs." They included two sub-categories: the dyemshi daukade, songs of cutting trees, which were sung when cutting down a big tree used for making a canoe, and dyemshi sare, running songs, which were sung when Bachama men were on a hunting expedition.

Dyemshi bondiha: songs of praise.

Dyemshi lagarato: songs of grinding corn which were sung by women early in the morning. 
Dyemshi tuto: songs of mourning which also included the category dyemshi gübawe.

This list of songs and tunes comprises a total of 24 highly specialized categories and sub-categories. The songs could transmit the message that a specific activity was taking place (e.g. hunters returning home, the cutting of grass), and they could transmit emotions (e.g. of abuse or mourning). The songs, then, combined three affective dimensions: the acoustic (the sound of the tunes), the verbal (the words of the songs), and the bodily (through the performance of the songs). Together, they formed an acoustic register through which meanings and emotions could be transmitted with a high degree of affective variation, nuance, and precision, and in this way they formed a pool of acoustic idioms which were used by both Bachama Christians and their opponents. They could transmit precise messages and emotions through sound and this was also taken up by the Bachama Christians.

I shall illustrate an affective and acoustic approach to Bachama Christianity with two examples. The first is the song of "the deaf one,"18 nzo gbinge, which was one of the many names of the greatest Bachama spirit, or püle, Nzeanzo. The name implied that Nzeanzo was so powerful and superior that he did not have to listen to others if he did not want to. ${ }^{19}$ Each year the Bachama performed their most important ritual, the vönön, in the village of Farei outside Numan. ${ }^{20}$ The song was sung for Nzeanzo by a group of women, the jibwepüle (those who follow the spirits), and as they sang their song specifically for Nzeanzo they were also known as the duwe da Nzeanzo (the horses of Nzeanzo). The song therefore belonged to the category of dyemshi jibwepüle (songs of those who follow the spirits and who sing to Nzeanzo during the vönön ritual). They sang the following song:

\footnotetext{
18 Cf. Kastfelt, "Afrikanske sange."

19 Interview with Dr. Nicholas Pweddon, Numan, 20 October 1994.

20 On Nzeanzo and the vönön festival see Phillips Stevens, Jr., "The Bachama and Their Neighbors: Non-Kin Joking Relationships in Adamawa, Northeastern Nigeria" (Ph.D. diss., Northwestern University, 1973), 268-284; Niels H. Brønnum, Under Demoners Aag. Bachamafolkets Religion og Overtro (Copenhagen: O. Lohse, 1926), 11-56; Damien Bitrus Asodati, The Mysteries of Nzeanzo and the Vunon Festival of Fare (Wukari: Amune Press, n.d. [1990]).
} 
1.

Myadupori, hunko kwai nzo gbinge

kadon mya po jigu

ndabo kango kuna njiya

a shafe kango byelloyo?

2.

Huno myaduporikun kanzogbinge

nzo gbinge diyadu

myapojigu ndabo kanga kuna njiya

a shafe kango byelloyo? ${ }^{21}$

English translation:

1.

Nobody will beg me, I refuse you the deaf one

In the past nobody begged your grandfather

When he stood and picked up earth

At the shrine and stood and talked?

2.

I, nobody will beg me, with the deaf one

The deaf one asks,

Was your grandfather begged when he stood and picked up earth At the shrine and stood and talked?

The song was addressed to Nzeanzo and to the Bachama who attended the shrines of the spirit. The women stressed - either speaking in their own voices or in that of Nzeanzo (verse 2, lines 2-4) - that it is not necessary to beg them to come and worship Nzeanzo ("picked up earth at the shrine and stood and talked"). They go to his shrine voluntarily and, like their grandfathers, they are faithful and loyal to Nzeanzo. The main point of the song is to encourage the Bachama to stick to their customary ways as their forefathers had always done before them.

Sometime in the 1920 s or perhaps early 1930 an unknown Bachama composed a Christian song based on the traditional "song of the deaf one." The words of the song were:

21 This and the following songs were both recorded in the house of Mrs. Sadaro and Mr. Nafuku Raymond Mamuno in the village of Imburu on 18th September 1994. The song was performed by a group of 10-12 Bachama women from Imburu. In transcribing the songs I have followed the spelling offered by Mr. and Mrs. Mamuno which on a number of points differs from what is generally accepted as standard Bachama orthography today. 
1.

A myawara ka hiuto hyeke yetanya

Fera Yesu a shikan

Yebo kango tago, Ila, Ila, hun kuso

Penge

2.

Atedu kodo lakau badumo wedau

Jikotto be luhambo

Bware, Yesu a sauna suno tufe

Hunaka tufe, madda woyo kyama

Nai

English translation:

1.

You have been called with prayer, you refuse and you quarrel

On the day Jesus comes back

You will be standing saying, Allah, Allah, I have fallen into

a trap

2.

You cannot follow that other way up to your death

Christians have occupied the whole place

People, Jesus tells you he is the way

You refuse the way, you sit and work and are going to different

places.

The song is a call to the Bachama to follow Christianity so that on the day of Jesus' return they will not find out that they have been trapped. They are encouraged to leave "that other way" - their traditional religion - and to follow Jesus instead of going to "different places" - to the traditional places of worship.

For the present purpose the main point about these two songs is that the new Christian song was composed in the acoustic idioms of a traditional tune, one of the dyemshi jibwepüle. To Bachama people at the time the specific tune of the song in itself had connotations for listeners that related to the powerful and superior Nzeanzo, to the need to follow tradition, and to the obligation to be faithful to the spirits. These were sensations that were produced by the very sounds of the song and they were then materialized by the words. The sound of the tune shaped the fundamental affective direction of the songs, which was then verbalized in specific detail. The new words of the Christian song struck the same theme as the traditional one by calling on the Bachama to follow the right path, which in this case was Christianity. The sounds of the old song 
conveyed a fundamental affective appeal, which was then verbally transformed and brought into the Bachama church by the new words and familiar sounds. What defined the fundamental character and appeal of the song was not the words as such but the meaning and affect created by their acoustic context.

\section{A Song of Loss and Mourning}

The following song shows us another aspect of the sounds of Bachama Christian history, or rather anti-Christian history because the song was composed against the introduction of Christianity. Just as Bachama Christians and missionaries composed new songs to promote Christianity, so their opponents composed songs against the Christians. Religious polemics in Bachama society in the early twentieth century very much took the form of songs and sounds, and this is how the polemics has been transmitted to us today.

Around 1930 the following song was composed by one of the most respected and admired Bachama composers, Nzakole Sondo, ${ }^{22}$ to his close friend and age-mate, Habila Aleyideino. ${ }^{23}$ Sondo and Habila were friends, growing up together in Numan, and both were expected to become jiboshe (sing. nzoboshe). A nzoboshe was a man who could see and exorcise spirits and, in addition, Sondo became a kura (one who can shoot without missing), the title of one of the leading and most experienced jiboshe. Instead of becoming a nzoboshe, however, Habila decided to become a Christian and was baptized with his father Iguda in $1926 .{ }^{24}$ Sondo was greatly disappointed by what he saw as his friend's desertion from tradition and their shared destiny. He therefore composed a dyemshi tuto against Habila around 1930, a song of mourning consisting of five verses each having one line which was repeated.

1. Kada ngbange a biyo dake

2. Na ngur gbra ta weyi kan

3. Nda muno na huro pula bagi a nya kei na kehe?

4. (Hina) weyo ka nduwa kpegun na we go we ma?

5. O, hya weyo vawe we go we be na sunga

22 This version of the song was performed by Mr. Boniface Vunodakai in Numan on 18th October 1994. The translation is by Nicholas Pweddon and Niels Kastfelt. See also Pweddon, "Dyemshi Bondiha."

23 See the brief biography by Musa A.B. Gaiya, "Habila Aleyideino c. 1907 to 1992, United Church of Christ (HEKAN), Nigeria," last modified 2003, http://www.dacb.org/stories/aaprint-stories/nigeria/aleyideino_habila.html, accessed October 9, 2012.

24 See Niels H. Brønnum, Iguda. En Fortcelling fra Afrika (Copenhagen: O. Lohses Forlag Eftf., 1933). 
English translation:

1. The stick of the mat has broken and left me with nothing.

2. I carry the bag and keep on walking with it.

3. What have I stolen (since) the spirit of my father quarrels with me so that I am weeping?

4. (We) walk with my fellow men, the two of us, what would make me fear death?

5. Oh, you will be afraid (and) fear death when he sees the sword?

\section{Commentary:}

1. "The stick of the mat" is the stick holding the zana mat which encircles a traditional Bachama compound. Here it describes the stick or pillar of tradition. Habila has broken the stick by becoming a Christian and has left Sondo "with nothing," with a broken tradition.

2. "[T] he bag" is "tradition" and the traditional Bachama way of life.

3. "[T] he spirit of my father quarrels with me so that I am weeping" refers to Sondo's walking around, burdened by the spirit of his father and weeping because he cannot find help to continue the traditional way of life.

4. "([W]e) walk with my fellow men, the two of us, what would make me fear death?": Sondo addresses Habila and says that if they had walked together as age-mates and had both become jiboshe they would have had no reason to fear death.

5. Sondo sadly asks Habila if his reason for leaving tradition is that he will "fear death when he sees the sword," referring to the swords or spears used in the initiation rituals of the jiboshe.

The song gives us a rare chance to sense some of the emotional loss associated with the introduction of Christianity. Such sensations are not exceptional but often difficult to reconstruct historically. The main tone of Sondo's song was contained in its tune, which colored its words. It was a dyemshi tuto, a song of mourning, and any Bachama hearing Sondo's song would know that it expressed mourning, sadness, and loss. Unlike most other songs against the Christians this one was not a dyemshi daha, a song of abuse, which is offensive and disparaging. It was full of sadness and grief at the loss of tradition and the loss of a friend.

The affective meaning of sound comes out clearly in the passage in Verse 3 where Sondo asks what he has done that he must walk around alone weeping. If the song had been one of abuse Sondo's weeping would no doubt have sounded abusive, but since the tune of the song belonged to the category of mourning songs, the tune in itself told the listeners what Sondo's weeping was about - not about abuse or offense but a lamentation of loss. The sound shaped the meaning of the words, and when we know the category of the tune we can understand the affective meaning of the sound. 
This chapter has offered a preliminary analysis of some aspects of sound in the history of an African Christian tradition and has indicated one way of writing such a history. In the many dimensions of African lived Christianity sound is important but generally understudied. Since many Africans experience Christianity not only through texts but also through sound, an acoustic approach is necessary to explore the varieties of African Christianity. It is quite common to refer to the Christians of African societies as "readers" 25 but we clearly also need to understand that they are "listeners." Hearing sounds must be integrated as strongly as reading texts into the study of African Christianity and, without advocating yet another compartmentalized field in exploring African Christianity, I would suggest that stronger attention be paid to its sounds.

\section{References}

Asodati, Damien Bitrus. The Mysteries of Nzeanzo and the Vunon Festival of Fare. Wukari: Amune Press, n.d. [1990].

Barber, Karin. The Anthropology of Texts, Persons and Publics. Cambridge: Cambridge University Press, 2007.

Brønnum, Niels H. “Den første salme paa Bachama." Sudan 6 (1914): 93.

Brønnum, Niels H. Folkeliv i Sudan. I. Bachamastammens Historie, Sprog, Levemaade og Kultur. Struer: M. Christensens Bogtrykkeri, 1923.

Brønnum, Niels H. Under Demoners Aag. Bachamafolkets Religion og Overtro. Copenhagen: O. Lohse, 1926.

Brønnum, Niels H. Iguda. En Fortcelling fra Afrika. Copenhagen: O. Lohses Forlag Eftf., 1933.

Cabrita, Joel. Text and Authority in the South African Nazaretha Church. Cambridge: Cambridge University Press, 2014.

25 See for instance John Lonsdale, "Kikuyu Christianities: A History of Intimate Diversity," in Christianity and the African Imagination. Essays in Honour of Adrian Hastings, ed. David Maxwell with Ingrid Lawrie (Leiden: Brill, 2002), 157-197; Peterson, Creative Writing; Adeline Masquelier, Women and Islamic Revival in a West African Town (Bloomington: Indiana University Press, 2009), 10-11. A fine starting point for studying the interaction of listening and hearing is John Lonsdale, "Listen while I read': The Orality of Christian Literacy in the Young Kenyatta's Making of the Kikuyu," in Ethnicity in Africa, eds. Louise de la Gorgendière and Kenneth King (Edinburgh: Edinburgh University, Centre of African Studies, 1996), 17-33. 
Conrad, Joseph. The Heart of Darkness, edited by Robert Kimbrough. Third edition. New York: W.W. Norton \& Company, 1988.

Corbin, Alain. Village Bells. Sound and Meaning in the 19th-Century French Countryside. Translated by Martin Thom. London: Papermac, 1999.

Darnton, Robert. Poetry and the Police. Communication Networks in Eighteenth-Century Paris. Cambridge, MA: The Belknap Press of Harvard University Press, 2010.

Feld, Steve and Donald Brenneis. "Doing anthropology in sound." American Anthropologist 31, no. 4 (2004): 461-474.

Fernandez, James W. "The Sound of Bells in a Christian Country - in Quest of the Historical Schweitzer." The Massachusetts Review 5 (1964): 537-562.

Gaiya, Musa A.B. "Habila Aleyideino c. 1907 to 1992, United Church of Christ (HEKAN), Nigeria." last modified 2003, http://www.dacb.org/stories/aa-print-stories/nigeria/ aleyideino_habila.html, accessed October 9, 2012.

Gunner, Elizabeth. The Man of Heaven and the beautiful Ones of God. Umuntu Wasezulwini Nabantu Abahle Bakankulunku. Writings from Ibandla lamaNazaretha, a South African Church. Studies on Religion in Africa XXIV. Leiden: Brill, 2002.

Hirschkind, Charles. The Ethical Soundscape. Cassette Sermons and Islamic Counterpublics. New York: Columbia University Press, 2006.

Hunt, Nancy Rose. "An Acoustic Register, Tenacious Images, and Congolese Scenes of Rape and Repetition." Cultural Anthropology 23, no. 2 (2008): 220-253.

Hunt, Nancy Rose. "Interview with Nancy Rose Hunt," "Acoustic register, tenacious images, and Congolese scenes of rape and repetition: supplementary material," http:// www.culanth.org./articles/106-an-acoustic-register-tenacious-images-and, supplement to Cultural Anthropology 23 (2008): 220-253, accessed March 7, 2016.

Hunt, Nancy Rose. "The Affective, the Intellectual, and Gender History." Journal of African History 55, no. 3 (2014): 331-345.

Hunt, Nancy Rose. A Nervous State. Violence, Remedies, and Reverie in Colonial Congo. Durham: Duke University Press, 2016.

Ikegami, Eiko. "Emotions." In A Concise Companion to History, edited by Ulinka Rublack, 333-353. Oxford: Oxford University Press, 2010.

Jensen, Mogens. Two Men and Their Mission. Anton Marius Pedersen, Niels Høegh Brønnum and the Danish United Sudan Mission 1905-1925. Translated by David Clayre. Christiansfeld: Forlaget Savanne, 1997.

Kastfelt, Niels. Kulturmøde i Nigeria. Mødet mellem Bachamafolket, engelske koloniembedsmeend og Dansk Forenet Sudan Mission. Copenhagen: G.E.C. Gads Forlag, 1981.

Kastfelt, Niels. Religion and Politics in Nigeria. A Study in Middle Belt Christianity. London: British Academic Press, 1994.

Kastfelt, Niels. "Afrikanske sange." Teol-information 14 (1996): 11-16.

Kastfelt, Niels. "A Song in Kwa Bwatiye by Dr. N.H. Bronnum." Linto 1 (1997): 5. 
Kastfelt, Niels. "Songs and Sleeping Sickness in a Nigerian Village." In (Genklange). Essays om kunst og kristendom tilegnet Nils Holger Petersen på 7o-årsdagen, edited by Kristoffer Garne and Lars Nørgaard, 176-182. Copenhagen: The Faculty of Theology, University of Copenhagen, 2016.

Kirsch, Thomas G. Spirits and Letters. Reading, Writing and Charisma in African Christianity. New York: Berghahn Books, 2008.

Lemefeme da Yesu Kristo. Markus. Shonga: British and Foreign Bible Society, 1915.

Lonsdale, John. "'Listen while I read'. The Orality of Christian Literacy in the Young Kenyatta's Making of the Kikuyu." In Ethnicity in Africa, edited by Louise de la Gorgendière and Kenneth King, 17-33. Edinburgh: Edinburgh University, Centre of African Studies, 1996.

Lonsdale, John. “Kikuyu Christianities." In Christianity and the African Imagination. Essays in Honour of Adrian Hastings, edited by David Maxwell with Ingrid Lawrie, 157-197. Leiden: Brill, 2002.

Malamto Dymsye. Bachama Hymn Book. Minna: The Niger Press, 1925.

Masquelier, Adeline. Women and Islamic Revival in a West African Town. Bloomington: Indiana University Press, 2009.

Myatafadi, Asriel S.T., Peter A. Bartimawus, Edward R. Ishaya and Elisabeth Holtegaard, eds. A Century of God's Faithfulness (1913-2013): Reflections on the Lutheran Church of Christ in Nigeria (LCCN). Numan: The Lutheran Church of Christ in Nigeria, 2013.

Nissen, Margaret. An African Church is Born. The Story of the Adamawa and Central Sardauna Provinces in Nigeria. Viby J.: Purups Grafiske Hus, 1968.

Page, Christopher. The Christian West and its Singers. The First Thousand Years. New Haven: Yale University Press, 2010.

Peterson, Derek R. Creative Writing. Translation, Bookkeeping, and the Work of the Imagination in Colonial Kenya. Portsmouth, NH: Heinemann, 2004.

Peterson, Derek R. Ethnic Patriotism and the East African Revival. A History of Dissent, ca. 1935-1972. Cambridge: Cambridge University Press, 2012.

Pweddon, Nicholas. "Dyemshi Bondiha: Bachama Praise Songs from Sondo to Rakuma Pwakono." Unpublished paper. Madison: University of Wisconsin, Department of African Languages and Literature, 1973 .

Pweddon, Nicholas. A History of the Lutheran Church of Christ in Nigeria (LCCN). Numan: The Lutheran Church of Christ in Nigeria, 2005.

St. Augustine. St. Augustine's Confessions. Translated by William Watts, vol 2, Book X, Chapter XXXIII, 164-169. Cambridge, MA: Harvard University Press, 1988.

Stevens, Jr., Phillips. "The Bachama and Their Neighbors. Non-Kin Joking Relationships in Adamawa, Northeastern Nigeria." Ph.D. diss., Northwestern University, 1973.

Sundkler, Bengt. Zulu Zion and Some Swazi Zionists. Oxford: Oxford University Press, 1976. 